539.979

744

U9g $6 h$

1985

\section{GRIZZLY BEAR HABITAT COMPONENT}

\author{
MAPPING HANDBOOK
}

for

\section{THE YELLOWSTONE ECOSYSTEM}

PLEASE RETURN

David J. Mattoon

Don G. Despain

STATE DOCUMENTS COLLECTION

\section{A.UG 121986}

MONTANA STATE LIBRARY

1515 E. 6th AVE.

HELENA, MONTANA 59620

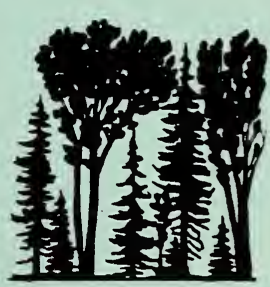


MONTANA STATE LIBRARY

5639.979744 Uspbh 1965 c. 1 Malteon
Grizzly bear habitat componem mapping h

30864000525413 


\title{
GRIZZLY BEAR HABITAT COMPONENT \\ MAPPING HANDBOOK FOR \\ THE YELLOWSTONE ECOSYSTEM
}

\author{
David Mattson - Interagency Grizzly Bear \\ Study Team \\ Don Despain - Yellowstone National Park
}

May 1985

MONTANA STATE UIBRARY

1515 E. Gh AVE.

HELENA, AONTANA 59620 

TABLE OF CONTENTS

INTRODUCTION.

BACKGROUND OF GRIZZLY BEAR HABITAT MAPPING $\ldots \ldots \ldots \ldots \ldots \ldots \ldots \ldots \ldots \ldots$

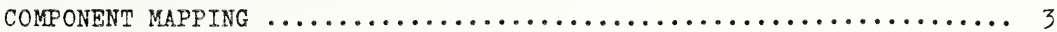

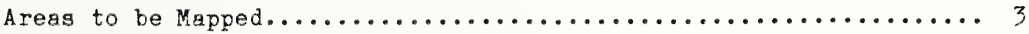

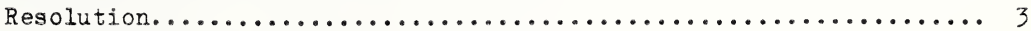

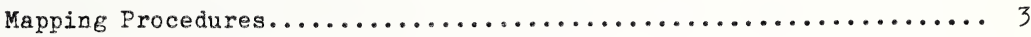

Prefield................................... 4

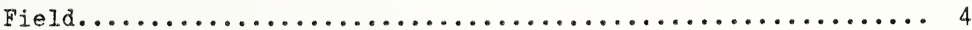

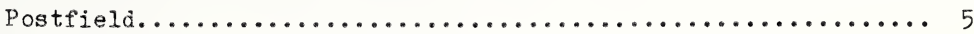

FORESTED HABITAT COMPONENTS....................... 8

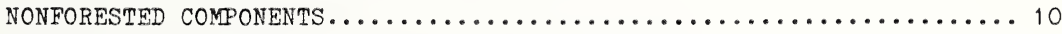

Description of Nonforested Habitat Components............... 11 PROTEIN-RICH HABITAT COMPONENTS........................ 18

Description of Protein-Rich Components..................... 19

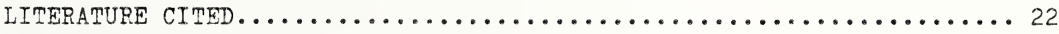

APPENDIX A Field form for component mapping.................... 33 APPENDIX B Plant species important to grizzly bears............25

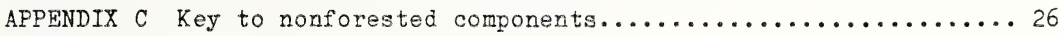

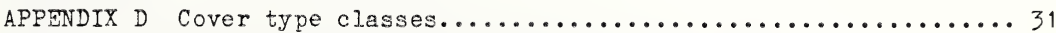




\section{Digitized by the Internet Archive in 2017 with funding from Montana State Library}




\section{INTRODUCTION:}

The continued existence of grizzly bears in the Greater Yellowstone Ecosystem is largely dependent upon the maintenance and improvement of suitable habitat in the face of increasing pressure for the development and recreational use of lands within that ecosystem. Successful management of habitat is based upon knowledge of the habitat requirements of the grizzly bear, the spacial distribution and description of habitats which meet these requirements, and the effects of human activities on habitat quality and habitat use. The mapping of all levels of grizzly bear habitat allows the resource manager to make calculated decisions based on quantifiable data.

The purpose of this handbook is to provide a method to describe and delineate grizzly bear habitat in the Greater Yellowstone Ecosystem.

This book is the result of much effort by several people. Tom Puchlerz, John Weaver, Mark Orme, and several field technicians reviewed and used earlier manuscripts of this handbook. Their comments and suggestions made this a more useful document. Margaret Holland and Linda Miller provided excellent typing and word processing help.

\section{BACKGROUND OF GRIZZLY BEAR HABITAT MAPPING}

Many efforts have been made to describe and quantify grizzly bear habitat quality and features, especially since the bear was declared a threatened species in 1975. The variable nature of grizzly bears and grizzly habitat and the different backgrounds and orientation of the researchers involved have led to a variety of methods to quantify habitat.

Habitat component classification systems are one of these methods and have been used as a means to describe and qualify important units of wildlife habitat. A habitat component as defined by Thomas et al. (1979) is "a simple part, or a relatively complex entity regarded as a part, of an area or type of environment in which an organism or biological population normally lives or occurs." Application of this concept has occurred primarily in western Montana (Mealey et al., 1976, Servheen and Lee, 1979, Zager et al., 1980) and most recently by Christensen and Madel (1982) on the Kootenai National Forest. The components described for use on the Kootenai are currently being used throughout the northern grizzly bear ecosystems.

Within the Greater Yellowstone Ecosystem, grizzly bear use of habitats is well documented from the Craighead's work of the sixties through today's efforts by the Interagency Grizzly Bear Study Team. At the present time, the Interagency Team is completing preliminary analysis of grizzly habitat use based on standardized cover types and standardized forest and nonforest habitat types.

It is apparent from the data available that grizzly bears within the Yellowstone Ecosystem make extensive use of both forested and nonforested 
habitat types. Forested types have importance both for foraging value and cover needs. Due to this known use of significant acreage of forested habitats, habitat components within the Yellowstone Ecosystem are broken into two major groupings: 1. Forested Habitat Components which represent the present overstory vegetation in forested areas and; 2 . Nonforested Habitat Components representing shrublands, grasslands, meadows, and naturally maintained forest openings.

The Habitat Type concept (Daubenmire, 1968) makes use of the fact that plants are integrators of all the environmental factors affecting an area. Certain plants can be used to indicate the particular environmental complex of a site and the climax plant community to be expected in that area. Aside from the influence of the soils and climate of a site that determine the kinds of plants occurring on a site, the time since last disturbance or successional stage is also important. In forested communities, this is indicated by the timber type (cover type) or stand structure. Knowing the vegetation type (habitat type plus cover type) it should be possible to predict, within reasonable limits, the existence and abundance of plant species of an area of interest.

Mapping of stands of similar vegetation type indicates the abundance and distribution of plant species of concern, such as those used as food by grizzly bears, and gives an indication of the vegetative value of an area to the grizzly bear.

Animal food sources are not as closely predicted by habitat type and cover type as are vegetal food sources. Additional areas need to be mapped which correspond to the availability of animal food sources, primarily ungulates and spawning fish.

These areas which require delineation are (1) ungulate winter ranges, (2) areas of carrion concentration on ungulate winter ranges, (3) traditional ungulate calving grounds, (4) areas of ungulate concentration on summer and fall ranges, and (5) streams hosting fish spawning runs. Overlaying these areas, which delineate availability of ungulates or fish, onto base maps of forested and nonforested components identifies map polygons with available concentrations of animal protein. Thus protein-rich areas are defined which represent both spawning streams and forested and nonforested components that support concentrations of ungulates. 
Component mapping is, in essence, the vegetative stand typing of all areas within a grizzly bear menagement unit. The identification and delineation of habitat components in the field requires a significant amount of time and effort. Restrictions in funding preclude complete ground mapping. Habitat components, however, can be accurateiy delineated by aerial photo interpretation combined with ground truthing of a select sample of the habitat components.

Areas to be Mapped - As habitat mapping will be the basis for cumulative effects assessments in the future, it is necessary that all habitat within identified grizziy bear management units be mapped to the standards identified in this handbook. Selection of units to be mapped should be based upon areas of grizzly bear management concern. Items to be considered in selection of units are:

1. Units with high probability of grizzly bear mortality or displacement.

2. Units subject to management activity such as timber harvest, oil and gas exploration or development, hard rock mining, grazing, and heavy recreation use.

3. Current management stratification (e.g., Management Situation 1 , Management Situation 2, etc.).

4. Areas adjacent to currently designated occupied habitat that are suspected as having potential for grizzly bear use.

Resolution - Habitat should be mapped to the following minimum standards:
Forested Habitat Components - 5 acres
Nonforested Habitat Components - 5 acres
Ungulate Components - 2 acres
Spawning Streams - Al1 (linear measure)

Mapping Procedures - Mapping procedures must be consistent and produce a readable, reasonably accurate product which will also meet the needs of the cumulative effects analysis process. Some districts may have most of the necessary data already collected for some other project such as range or timber surveys. Often there are plot sample data available from these surveys. These sources should be used to cut down on field time, check the accuracy of the field crews, and to interpolate mapping to photos that were not ground checked. If such sources are not available for an area of concern then we offer the following steps as one method to achieve the desired product.

Mapping can occur in three phases, prefield, field, and postfield. The prefield phase consists of stand delineation on airphotos and sample stand selection. Field work provides ground identification of selected sample 
stands delineated in the prefield phase and collection of verification plot data. The postfield phase is interpolation of information from the visited plots to all the other plots on the photo and adjacent unvisited photos. The prefield and field phases would best be conducted concurrently so that experience gained in the field can help in the prefield photo interpretation.

When writing the vegetation types on maps or photos use a five-digit code to conserve space. For the forested types the first three digits are the Habitat Type ADP codes found in the Habitat Type manuals (Pfister et al., 1977, p. 6; and Steele et al., 1983, p. 12). The last two digits are the cover type code found in Appendix D. The nonforested type codes all begin with three zeros. These codes can be found on both the descriptions and the key to the nonforested components (Appendix C).

Prefield: Obtain good color or color infrared photography, preferably large scale (e.g. 1:15840) for the area to be mapped. Black and white photography usually will not provide sufficient resolution in the nonforested areas. Delineate homogenous-looking stands on each photograph's effective area (the center plus one-half the area of overlap with adjacent photos). Provide each different type with a temporary provisional designation $(1,2,3$. . ) only as an aid to sample stand selection.

Time and money will not permit on-the-ground sampling of every stand, therefore select a sample of air photos to be checked. Usually a systematic sample of every other photo of every other flight line will provide good coverage, however care should be taken to be sure the entire range of variation within the area will be sampled. Photos with a great deal of complexity would be preferred for sampling to photos with just a few types. Once the photos are chosen, stands within the photo need to be selected. Criteria for selection should be ease of access to and proximity of stands which will, at the same time, obtain a sample of at least one of each of the provisional classes.

Field: Plan travel routes carefully to get to the greatest number of stands in the shortest time. Plotting sample stands on a trails map may help. Take into the field all airphotos that will be crossed during the trip. In the field, identify on the photo or its overlay the vegetation types of all the delineated stands you cross getting to the sample stand. Make note of any changes in lines that should occur.

Once you reach the sample stand, determine vegetation class and record it on the photo. If fuller information is deemed necessary for future reference or to fill in gaps in existing data, the plot form in Appendix A may be used. Fill in the plot form header and record cover values for all the species that have greater than five percent cover, all the indicator species needed for habitat type determination (you may want to use the field form in the Habitat Type manuals for these species), and all important bear food plants (Appendix B). Cover class definitions are on 
the data sheet. For each tree species record also the size classes present ( $\mathrm{S}=$ Seedling/Sapling, $\mathrm{P}=\mathrm{Pole}[1-7 \mathrm{in} . \mathrm{dbh}], \mathrm{M}=$ Mature, OM=Ove rma ture; underline prominent class). Then write a short narrative description of the stand in a $l \circ g$ book and mark plot location on air photo.

Equipment needed in the field will include airphoto carriers, pencils, plot forms, compass, and clinometer. If camping out, remember you are in bear country and act accordingly.

Accuracy of the mapping effort is a concern that needs to be addressed. At the present time there does not seem to be an efficient method of checking the field accuracy of the maps. However as you travel around the area covered by earlier mapping efforts it would be a good idea to take a copy of the maps and check them against what you see on the ground. This way you will get a good feel for their accuracy. Experience has shown that the methods described here will obtain approximately 80 percent accuracy. Maps will be reassessed as methodology is developed to better determine mapping accuracy.

Postfield: Once the sample photos have been field checked, these photos can be used to identify other stands on the photo and those on adjacent photos. Once all stands are identified with the five-digit code, the information can be transferred to $71 / 2$ minute base maps. Orthophoto quads provide an easy way to do this.

A base map and two overlays need to be developed for each $71 / 2$ minute orthophoto quad.

1. The base map is habitat/cover type polygons (delineated in black or red ink) on a $71 / 2$ minute orthophoto reproduced on mylar. Polygons should be labeled internally where possible with five-digit code. Delineate polygon labels and leader lines if label is outside polygon with a different color ink than that used for polygon boundaries, and be consistent. Polygons that are a mosaic of habitat/cover types should be labeled with a ten-digit code (e.g. 53440/53441). The dominant habitat/cover type should be recorded in the first five digits of the ten-digit code. Areas outside of mapped area should be labeled Nu (meaning outside area of consideration).

2. One mylar overlay with polygons delineating protein-rich areas labeled with the two-digit alpha code given in the section on protein-rich components (pages 19-21) will supplement the base map. Polygons that are a combination of protein rich areas should be labeled with all appropriate codes (e.g., MW/EW). Use black ink to delineate polygons and red ink to delineate fish spawning streams. Label "background polygon" Nu.

3. After completion of the habitat component mapping, an additional overlay for each $71 / 2$ minute quad of all existing activities and human uses needs to be prepared for digitizing. Delineate all linear, point, and dispersed activities on a frosted mylar overlay using a fine line, permanent ink pen (i.e., felt tip fine liner, rapidograph, etc.). Outline 
and label dispersed use polygons in green, delineate linear features in blue, and mark point source activities with a red " $X$ ". Different colors for the three major categories will help avoid confusion when digitizing. If activities overlays are sufficiently complex (e.g., approximately 70 polygons and 70 line segments), delineate the polygons on one mylar and lines and points on a separate mylar. Do not separate on two mylars if less complex, as this will increase digitizing costs. Use a yellow highlighter to mark line segments that are both linear features and polygon boundaries. Label polygons internally and label each line segment of linear features (Figure 1). Number polygons, points, and line segments on overlay from 1 through $n$. Attach an attribute table for each number which identifies the type of activity (Table 1) and the duration that the particular activity code is valid. It is possible to have more than one activity code per polygon or line segment, etc. For example, line segment 5 (Figure 1) may be a 111 (motorized linear high use) from June 10 through September 5 and 112 (motorized linear low use) for the remainder of the year. However, each polygon, line segment, or point should have only one label on the mylar overlay. Line segments that constitute the same road, trail, etc., and have the same attributes (e.g., similar activity duration, intensity, and potential for management) should have the same label on the mylar.

When preparing inylar overlays be sure to clearly and accurately nark and label (lat./long.) the corners of the quads and write the name of the quad and type of overlay on the mylar. Make sure the entire quad is completed and "edge matched" with adjoining quads before sending in for digitizing. Where polygons overlap with adjoining quads, close the polygon by delineating the map border (Figure 1 ).

Write on frosted side of the mylar and plesse use a permanent fine line pen (i.e., pilot fineliner, rapidograph, etc.) on base map and all overlays. Make sure polygons are closed, lines are fairly even and dense, and the map contains no extraneous items. Before mailing completed quad, make copies and pencil in overlapping polygons and linear features on adjoining quads. These copies will be needed for backup and will aid in "edge matching." Information at the edge of one quad must agree with information on the adjacent edge of adjoining naps. If adjoining quads are mailed simultaneougly, please make sure all polygons or iinear features (roads, trails, etc.) are edge-matched. Coordinate edge-matching and myiar preparation with adjoining forests, districts, and parks. Deliver quads for digitizing with data from all districts and forests on the same mylar.

Several common errors that are detected during and after digitizing are shown in Figure 2. These can generally be avoided by careful preparation and careful checking before submission for digitizing. Changes to digitized maps can be quite costly so careful checking is necessary.

Try to send maps as they are completed (i.e., every ten days) rather than stockpiling and sending all at once. This will allow us to maintain a relatively even flow of maps to the digitizer. If you need assigtance in 
Figure 1. Example of protein-rich overlay.

$110^{\circ} 00^{\circ}$

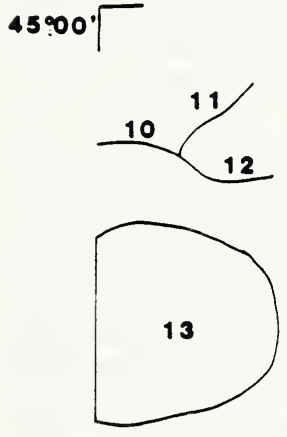

$44 \circ 5$

$110^{\circ} 00^{\prime}$

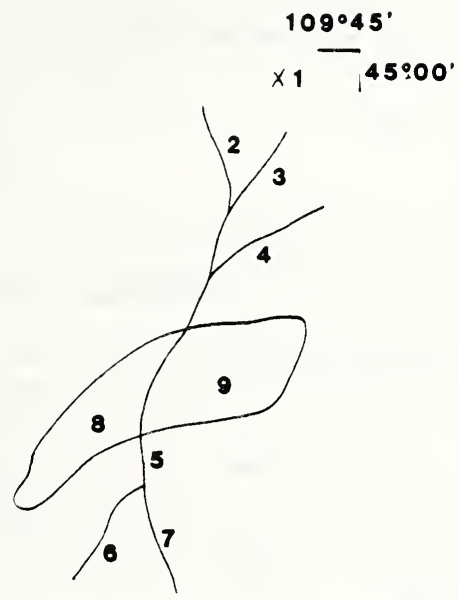

$44^{\circ} 45^{\circ}$

\section{PILOT PEAK}

Figure 2. Common digitizing errors.
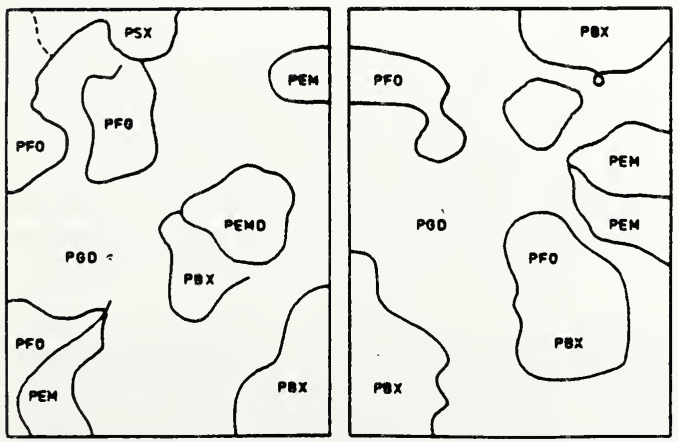

- edge matching

- polygon labeling

- closure of polygons

- bisecting line

- OVERSHOOT

- extra attribute

- missing attribute

- LoOP

- misclassified attribute

- missing line 
preparing maps for digitizing, please call Kim Barber at (801) 625-5263 or FTS 586-5263.

Send completed base maps and overlays to:

Kim Barber

Wildlife Management Staff

USDA Forest Service

324 - 25th Street

Ogden, Utah 84401

Table 1. Activity codes for "activities" map overlay.

\begin{tabular}{|c|c|}
\hline Activity Group & Map Code \\
\hline \multicolumn{2}{|l|}{ Motorized Linear } \\
\hline High Use & 111 \\
\hline Low Use & 112 \\
\hline \multicolumn{2}{|l|}{ Motorized Point } \\
\hline 24-hour & 120 \\
\hline Diumal High Intensity & 121 \\
\hline Diurnal Low Intensity & 122 \\
\hline Motorized Dispersed & 131 \\
\hline \multicolumn{2}{|l|}{ Nonmotorized Linear } \\
\hline High Use & 211 \\
\hline Low Use & 212 \\
\hline \multicolumn{2}{|l|}{ Ncnmotorized Point } \\
\hline 24-hour & 220 \\
\hline Diurnal & 223 \\
\hline Nonmotorized Dispersed & \\
\hline High Use & 231 \\
\hline Low Use & 232 \\
\hline Explosives & 304 \\
\hline
\end{tabular}


FORESTED HABITAT COMPONENTS

Forested components are those stands where coniferous or deciduous trees such as aspen (Populus tremuloides) are present or will return. All of these sites potentially support a closed canopy forest or a woodland of regularly spaced trees. Recently burned or harvested sites which will support forest stands are considered to be forested components in the very early successional stage.

Components are defined primarily by standardized habitat type and present overstory or cover type. Tree species and structure are easily discerned from aerial photographs facilitating identification and mapping of components are therefore facilitated.

Cover types represent the present overstory vegetation. With disturbance from both fire and harvesting so prevalent in this ecosystem, these cover types become a classification of the continuous process of succession.

The cover type classes are post-disturbance, early, mid-and late successional, and climax stands described in Appendix D. Difficulty may be encountered in deciding, for example, if a stand is early mid-succession or late early succession. The errors should average out, i.e., you should place as many too high as you place too low.

The description of each stand will include both the habitat type and the cover type. Habitat types used in eastern Idaho and western Wyoming will accord with Steele et al. (1983) while habitat types used in Montana will accord with Pfister et al. (1977).

Aspen present a special case. Aspen cover types occur where aspen composes greater than 50 percent of the forest canopy. Successional stages range from sapling to overmature. Conifer tree species may or may not be present.

Aspen stands with coniferous tree species present and reproducing successfully will be given a habitat type designation according to the references listed above. Aspen stands without significant representation of conifer species will be rated as wet (901), moist (902), or dry (903), based on understory species composition and site condition. This site moisture rating will substitute for a habitat type designation. Forb and graminoid species used as indicators of the various moisture conditions in nonforest components can also be used in aspen stands.

Mixed forest stands may also be encountered. These stands are characterized by the well-represented presence of at least two tree species, typically in all age classes represented. One of the two (or more) species is a "late successional" species (e.g. subalpine fir, engelmann spruce), the other is "early successional" (e.g. lodgepole pine, douglas-fir). 
The important distinguishing characteristic of a mixed forest stand is the apparent establishment of "early" and "late" successional tree species at stand initiation, and the continued presence of these ecologically diverse species throughout stand development. No one tree species is predominately older. An example would be a pole-sized stand, half douglas-fir and half subalpine fir.

Continue designating MF stands with the most appropriate pre-existent classification, but also give the stand an MF designation.

\section{NONFORESTED HABITAT COMPONENTS}

Nonforested components include shrublands, meadows, grasslands, and naturally maintained forest openings. Exposed bedrock, talus, open water, and stream-courses are also included. All of these sites do not potentially support a closed forest canopy or a woodland of regularly spaced trees. Recently burned or harvested sites which will support forest stands are therefore not considered to be nonforested components.

Nonforested components represent aggregates of two to five habitat types. These components are therefore coarser units of landscape definition than are individual habitat types. Wetland, forb meadow, and shrubland/ grassland habitat and community type classifications of Mattson (1984), Gregory (1983), Mueggler and Stewart (1980), and Tweit and Houston (1980), are incorporated in this component classification.

Components are defined primarily by vegetation stmucture and site moisture and secondarily by differing nature and intensity of grizzly bear use. Vegetation structure and site moisture are used to discriminate components primarily to facilitate field identification of components. Vegetation structure and landscape factors related to site moisture are easily discerned from aerial photographs. They are also more readily learned than the floristics required to separate individual nonforested habitat or community types.

Descriptions of nonforested components follow. A key is found in Appendix C. 
Description of Nonforested Habitat Components

I. Shrub Dominated Components 00010 :

TALI SHRUB COMPONENT O0011

tall shrub community

Sites typically occur on floodplains and along streamides. Tall willow species usually $>1.5 \mathrm{~m}$ tall at maturity (e.g. Salix geyeriana, S. boothii, S. bebbiana, and $S$. drummondii) are characteristic dominant shrubs. Alder (Alnus tenuifolia) and birch (Betula spp.) may be present or even dominant. Undergrowth is varied; Agropyron caninum, Pos pratensis, Calamagrostis canadensis, Carex microptera, C. rostrata, Geum macrophyllum, and Fragaria virginiana are often present and sometimes abundant. Soils are

depositional; typically medium textured mineral alluvial or less of ten, shallow (<30 cm deep) peat. Sites usually occur below $7500 \mathrm{ft}$. (2275 m). High elevation sites include those occurring above $7500 \mathrm{ft}$.

MESIC-HYPERMESIC SAGEBRUSH/CINQUEFOIL COMPONENT 00012 moist sagebrush/cinquefoil shrub meadow

Sites occur on moist benches, floodplains, and hillsides with north and east exposure. Artemisia tridentata-vaseyana and A. cana are characteristic dominant sagebrush taxa; Potentilla fruticosa (shrubby cinquefoil) is occasionally dominant or codominant. Festuca idahoensis, Agropyron caninum, Bromus carinatus, B. anomalous, Danthonia intermedia, Potentilla divergifolia, P. gracilig, Geranium viscossissimu, Phleum Alpinum, Dechampsia cespitosa, and Carex microptera are often present and sometimes abundant. Herbaceous vegetation is typically dense, moderate statured (ca. $6 \mathrm{dm}$ ), and diverse. Soils are characteristically medium textured, well developed, and deep. The Artemisia'tridentata/Festuca idahoensis-Geranium viscossissimum phase and Artemisia cana/Festuca idahoensis, Potentilia fruticosa/Festuca idahoensis, Artemisia cana/Carex microptera, and Artemisia cana/Carex aquatilis habitat types are

characteristic of this component. Sites occur most frequently above 7000 ft. $(2125 \mathrm{~m})$. High elevation sites include those occurring above $7500 \mathrm{ft}$.

MESIC/LITHIC SAGEBRUSH COMPONENT 00015

moist rocky sagebrush shrubland

Sites occur on upslopes, low ridges, and rocky elevated floodplains. Artemisia tridentata-vaseyana is the characteristic dominant sagebrush. Moist site forbs and graminoids comprise most of the herbaceous vegetation. Wyethia spp. may be abundant on heavily overgrazed sites. Herbaceous vegetation is typicaliy moderate statured (ca. $6 \mathrm{dm}$ ) and diverse, but often moderately open. Bare ground and surface rock are characteristic. Soils include a high percentage of fractured rock or cobbles in a medium to coarse textured mineral matrix. This type is comon in areas with relatively high precipitation where edaphic factors primarily determine the distribution of sagebrush. 
SUBMESIC-SUBXERIC SAGEBRUSH COMPONENT 00013

dry sagebrush shrubland

Sites occur on convex or even topography and exposed, generally southerly facing, hillsides. Artemisia tridentata is the characteristic sagebrush species; Purshia tridentata and Chrysothamnus spp. are occasionally present. Festuca idahoensis, Agropyron spicatum, Koeleria nitida, Poa sandbergii, and Geum triflorum are often abundant. Herbaceous vegetation is typically low to moderate statured ( $c a .3-5 \mathrm{dm}$ ) and moderately open. Bare ground is usually evident. Soils are shallow to moderately deep and often rocky. The Artemisia tridentata/Festuca idahoensis-F. idahoensis phase and the Artemisia tridentata/Agropyron spicatum, Artemisia tripartita/Festuca idahoensis, Purshia tridentata/Festuca idahoensis, and

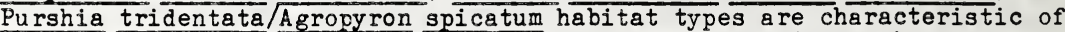
this component. Sites typically occur below $7500 \mathrm{ft} .(2275 \mathrm{~m})$.

\section{LOW WILLOW COMPONENT OOO14}

low willow shrub meadow

Sites occur in floodplains, peatlands, and on gently sloping seeps. Salix wolfii, S. eastwoodiae, S. planifolia, S. brachycarpa, S. glauca, and $\underline{S}$. commutata can be abundant or dominating. These willows are typically

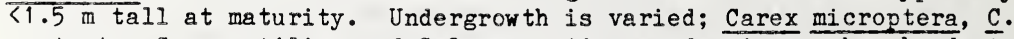
rostrata, C. aquatilis, and Calamagrostis canadensis can be abundant. Fragaria virginiana, Geum macrophyllum, Aster foliaceus, and Phleum alpinum are often present. Herbaceous vegetation is typically dense, although subordinate to dense clonal willow growth. Soils are peat or medium textured mineral alluvial. Surfaces can be dry by late summer or persistently saturated. The Salix wolfii series and Carex aquatilis/Salix Dlanifolia habitat type are characteristic of this component. Sites typically occur above $7500 \mathrm{ft}$. $(2275 \mathrm{~m})$.

\section{Herb Dominated Components:}

FORB MEADOWS 00020

SUBHYDRIC FORB COMPONENT 00021

forb dominated seep

Sites are typical of gently to moderately sloping, expansive to isolated and small seeps. Senecio triangularis and Mimulus spp. (M. guttatus, M. lewisii, M. moschatus) are characteristic dominants. Heracleum lanatum may also be abundant at lower elevations. Vegetation often occurs in a mosaic of varied stature. Soils are typically sandy or liquified. Saturation persists throughout the growing season. 
HYPERMESIC FORB COMPONENT 00022

wet forb meadow

Sites occur on north and east facing benches or hillsides which are influenced by seepage, sometimes from late snowmelt. Aconitum columbianum, Rudbeckia occidentalis, Mertensia ciliata, Heracleum lanatum, and Senecio triangularis are often present and sometimes abundant. Vegetation is typically dense, moderately tall to tall (ca. 6-10 dm), and diverse. Succulence is evident throughout the growing season. Soils are persistently wet to moist. Sites typically occur above $7500 \mathrm{ft}$. (2275 m). A high elevation variant of this component, in which Caltha leptosepala dominates low vegetation, occurs above $9000 \mathrm{ft} .(2725 \mathrm{~m})$. The Mertensia ciliata and Heracleum lanatum-Rudbeckis occidentalis comunity types and the Caltha leptosepala commity type at highest elevations are characteristic of this component.

MESIC FORB COMPONENT COO23

moist forb meadow

Sites typically occur on concave or convex hillsides with north, east, and, less often, south aspects. Ligusticum filicinum, Senecio serra, Delphinium occidentale, Aster integrifolius, Lupinus argenteus, Mertensia oblongifolia, Fragaria virginiana, Ceranium viscossissimum, Carex hoodii, C. raynoldsii, and Melica spectabilis are often present and sometimes abundant. Vegetation is typically moderately dense to dense, moderate to tall statured (ca. 6-10 dm), and diverse. Soils dry by late July or August with consequent dehydration of the vegetation. Pocket gopher (Thomomys thalpoides) activity is usually abundantly evident. The Ligusticum filicinum-Delphinium occidentale and Lupinus argenteus-Fragaria virginiana community types are characteristic of this component. Sites typically occur above $7500 \mathrm{ft}$. $(2275 \mathrm{~m})$.

SUBMESIC-SUBXERIC FORB COMPONENT COO24

dry forb meadow

Sites typically occur on ridges and southerly facing slopes. Balsamorhiza sagittata, Helianthella uniflora, Eriogonum umbellatum, Artemisia Iudoviciana, Valeriana edulis, and Phleum pratense all may be abundant. Vegetation is typicaliy open to moderately open and moderate statured (ca. 3-8 dm). Surface rock is typicelly quite evident. Soils and vegetation dry by mid-summer. The Balsamorhiza sagittata-Helianthella uniflora and Artemisia ludoviciana-Valeriana edulig community types are characteristic of this component. One variant of the dry forb meadow occurs at elevations $>8500 \mathrm{ft} .(2575 \mathrm{~m})$. On these sites adequate spring and early summer moisture support an ephemeral commity of Claytonia lanceolata and Erythronium grandiflorum on rocky soils. The Claytonia lanceolata-Erythronium grandiflorum comminity type is characteristic of this variant. 


\section{GRAMINOID MEADOWS AND GRASSLANDS 00030}

\section{SUBHYDRIC GRAMINOID COMPONENT 00031}

marsh/fen

Sites are low-lying and concave or occur on gentle slopes with seepage. Vegetation is varied; Carex rostrata, C. aquatilis, C. nebrascensis, C.

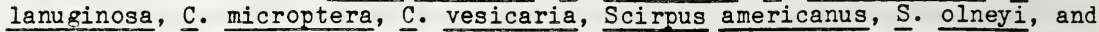
S. acutus may all be dominants. Carex limosa and C. buxbaumi i a re occasionally dominant in fens. Vegetation is typically dense and moderately tall to tall (ca. 6-20 dm); less often it is low and open. Dominance by only a few $(1-4)$ species is characteristic. Soils are often peaty; depths range from a few centimeters to a meter. Sites may be persistently inundated but are most often persistently saturated. Spring inundated sites which dry by fall are also included in this component. The Scirpus-Carex, Carex aquatilis-C. aquatilis, Carex rostrata-C. rostrata, Carex vesicaria-c. vesicaria, and Carex nebrascensis-c. nebrascensis habitat types are characteristic of this component. High elevation sites are considered to be those occurring above $7500 \mathrm{ft}$. (2275 m). Geothermally influenced marshes or fens occurring above $7500 \mathrm{ft}$. would be included in the low elevation type.

HYPERMESIC GRAMINOID COMPONENT 00032 wet meadow

Sites occur in floodplains, basin meadows, and on gently sloping seeps. Vegetation is varied but typically includes Deschampsia cespitosa, Phleum alpinum, Juncus balticus, Aster foliceus, Potentilla spp. or Carex microptera. Carex aquatilis, C. scopulorum, C. praegracilis, and c. nebrascensis are occasionally abudant. Vegetation is typically dense, moderate statured (ca. $6 \mathrm{dm}$ ), and moderately diverse. Greater species richness and diversity in part distinguishes this component from the subhydric graminoid component. Dehydration and browning may occur by early to mid-August due to early hard frosts. Soils are coarse to fine textured mineral and sometimes organic. Wet to moist conditions persist throughout the growing season. The Phleum alpinum and Deschampsia cespitosa series and the Carex aquatilis-Deschampsia cespitosa, Carex aquatilis-Pedicularis groenlandica, and Carex nebrascensis-Juncus balticus habitat types are characteristic of this component. High elevation wet meadow sites are considered to be those occurring above $7500 \mathrm{ft} .(2275 \mathrm{~m})$.

\section{MESIC GRAMINOID COMPONENT OOO33}

moist grassland and meadow

Sites occur on gently undulating topography, hillsides, and level or convex floodplains. Protected aspects are typical. Festuca idahoensis, Agropyron caninum, Bromus anomalous, Carex petasata, Phleum alpinum, Deschampsia cespitosa, Melica spectabilis, Geranimium viscossissimum, Potentilla gracilis, Aster integrifolius, and Polygonum bistortoides are often present 
and sometimes abundant. Sites potentially supporting a prominent forb component but currently dominated by graminoids occur in areas with a history of intensive sheep grazing. These sites are included in this component. These otherwise moist forb sites typically have an alundance of Carex raynoldsii, $\underset{C}{ }$. hoodii, and Melica spectabilis. For this type in general, vegetation usually dehydrates by late July or August due to drying soils. Soils are medium textured and moderately deep. The Festuca idahoensis-Agropyron caninum and Festuca idahoensis-Deschampsia cespitosa habitat types are characteristic of the mesic graminoid component. High elevation sites of this component are those occurring above $7500 \mathrm{ft}$. $(2275 \mathrm{~m})$.

\section{MESIC-SUBMESIC/LITHIC GRAMINOID COMPONENT 00034}

high elevation rocky grassland

Sites occur on upslopes and ridges with shallow soils having a high percentage of incorporated rock. Festuca idahoensis-ovina, Arenaria congesta, Delphinium bicolor, Erigonum umbellatum, Trisetum spicatum, Deschampsia elongata, Carex phaeocephala, and Lomatium cous are characteristic species at high elevations. Artemisia tripartita and Carex geyeri are more common at slightly lower elevations. Vegetation is typically low ( $c a .3 \mathrm{dm}$ ) and open; bare ground and rock are evident. The Festuca idahoensis-ovina-Arenaria congesta, Festuca idahoensis-ovinaDelphinium bicolor, and Artemisia tripartita/Carex geyeri communty types are characteristic of this component. Sites typically occur above $8000-9000$ ft. $(2425-2730 \mathrm{~m})$.

\section{SUBXERIC GRAMINOID CONPONENT 00035}

dry grassland and meadow

Sites occur on drier sidehill, flat, and convex topography typically with southerly exposure. Agropyron spicatum, Koeleria nitida, Festuca idahoensis, Poa sandbergii, Stipa richardsonii, S. comata, Agropyron dasystachyum, and Lupinus sericeus are often present and sometimes abundant. Vegetation is moderately dense to moderately open and low to moderate statured $(\mathrm{ca} .3-5 \mathrm{dm})$. Bare ground is often evident. Soils are medium textured and moderately shallow to moderately deep; drying occurs by early to mid-summer. The Festuca idahoensis-Agropyron spicatum, Festuca idahoensis-Stipa richardsonii, and Agropyron spicatum-Poa sandbergii habitat types are characteristic of this component. sites typically occur below $7000-7500$ ft. $(2125-2275 \mathrm{~m})$.

\section{Forest Opening Components 00040}

HYPERMESIC-SUBHYDRIC FOREST OPENING COMPONENT 00041 wet forest opening

Sites occur in swales and along stream courses where forest adjoins and shades during a substantial portion of the day. Calamagrostis canadensis, 


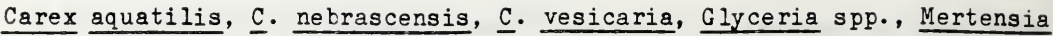
ciliata, and Senecio triangularis are of ten present and occasionally abundant. Sites include potholes inundated in spring which dry by fall. Vegetation is typically dense, moderately tall (ca. 6-10 dm), and of ten quite diverse. Foliage is characteristically succulent and green throughout the growing season. Soils are coarse to fine-textured and occasionally organic. The Calamagrostis canadensis series and the Carex nebrascensis-C. nebrascensis habitat type are characteristic of this component.

MESIC-SUBXERIC FOREST OPENING COMPONENT 00042 moist to dry forest opening

Sites typically occur on hillsides with adjoining shading forest. Vegetation more typical of forest understories extends into these openings, including Symphoricarpos spp., Ceanothus velutinus, Rosa spp., Arnica spp., Calamagrostis rubescens, and Carex geyerii. Soils are varied. In rare cases, Ceanothus velutinus with Symphoricarpos and Rosa spp. dominates extensive areas. These sites are included in this component.

\section{Miscellaneous Components:}

TUNDRA COMPONENT 00051

Sites occur above timberline on gentle to moderately steep topography. Elevation typically exceeds $10,000 \mathrm{ft}(3030 \mathrm{~m})$. Vegetation cover is more-or-less continuous. Site moisture varies from persistently saturated to exposed and droughty. All tundra vegetation and site types are included.

\section{EXPOSED REDROCK (SLABROCK) OR UNVEGETATED SOIL COMPONENT 00052}

Sites where predominantly unfractured bedrock or unvegetated soil is exposed; including gentle to steep slopes.

\section{TALUS COMPONENT 00053}

Sites where loose fractured rock is pervasive, typically on moderate to steep slopes. Vegetation cover is sparse or restricted to margins of the talus slope.

STREAM COURSE COMPONENT OOO54

Sites consist of perennial stream channels - predominantly unvegetated and occupied by flowing water during a substantial portion of the year; including occupied channels and adjacent bed of cobbles and boulders. 
Sites where standing water persists through most years, including pools, ponds, and lakes.

\section{CLIFF COMPONENT 00056}

Sites consisting of vertical to near vertical rock formations. Vegetation cover is sparse or restricted to microsites within the cliff complex where soil has collected.

SHRUB DOMINATED AVALANCHE CHUTE COMPONENT: 00057

Sites typically include seepage-influenced lower portions of avalanche chutes. This component characteristically occurs at lower elevations in areas of high relief and higher, especially winter, precipitation. Berry-producing shmbs, such as Sorbus spp. and Rubus spp. are often abundant.

GRAMINOID/FORB DOMINATED AVALANCHE CHUTE 00058

Sites are typically highly disturbed and occupy the basal portion of certain avalanche chutes. This component characteristically occurs in avalanche chutes with a higher elevation base. Forbs and/or graminoids form substantial cover often in mosaic with subalpine fir thickets hedged by frequent avalanches and draws or ravines scoured by snow and seasonal runoff.

AGRICULTURAL LANDS 00059

Sites where vegetation has been drastically modified by humankind for agricultural purposes; including hay meadows, seeded pasture, and cropland. This land has typically been plowed or disced at one time and native vegetation eliminated or greatly reduced.

URBANIZED AREAS 00060

Sites include areas where human activities have modified the natural environment, typically to the point of eliminating most native vegetation. An expanse of pevement is typical of this component. Sites specifically include towns, subdivisions, and airports. Summer home sites, farm and ranch buildings, and highway clearing strips are not included. 


\section{PROTEIN-RICH HABITAT COMPONENTS}

Protein-rich components include forested and nonforested areas which support or are close to available concentrations of animal protein, especially ungulates and fish. These components are identified on maps by overlays and by suffixes appended to the numeric codes of forested or nonforested component types.

Protein-rich components defined by the presence of ungulates correspond (1) to winter range types, (2) areas of carrion concentration on winter ranges, (3) traditional ungulate calving grounds and (4) a reas of concentration on summer and fall ranges. Identification of these components requires specific knowledge of ungulate movements and habitat relations as well as physiographic characteristics of winter range. This information is usually available from local Federal and State biologists.

Population status of wintering ungulate herds influences the amount of animal protein available to the bears. Herds need to be identified which during an "average" year, sustain significant winter-spring mortality. This mortality determines the presence of significant amounts of carrion and "walking dead". On the other hand, ungulate herds and corresponding ranges experiencing very little winter-spring mortality also need to be identified.

Protein-rich components reflecting fish availability are those spawning streams used or potentially useable by grizzly bears. These streams (1) host a sizeable run of spawning trout and (2) have physical attributes which allow them to be fished by bears. 
Description of Protein-Rich Habitat Components

I. UNGULATE DEFINED COMPONENTS

Winter Range Types

Component suffix - MW

Moose Winter Range

This type consists of areas where relative concentrations of moose are known to winter. Sites characteristically include floodplains or bottomland dominated by tall willows. Elevations are typically moderate. This type does not include scattered and isolated sites typically supporting only one or a small number $(<5)$ of wintering moose.

Component suffix - BW

Bison Winter Range

This type occurs primarily as extensive nonforested areas below $8000 \mathrm{ft}$. $(2425 \mathrm{~m})$. In places this winter range type corresponds with geothermal influence. Bison winter range should be mapped on the basis of more than incidental occupancy.

Componert suffix - E

Elk Winter Range

Elk winter on a variety of ranges in the greater Yellowstone area. Three winter range types are distinguished for mapping:

(1) geothermally influenced winter range, (2) higher elevation mountainous winter range, and (3) lower elevation valley winter range.

Component suffix - ET

Geothermally Influenced Elk Winter Range

This winter range type corresponds with geothermal influence. Duration and depth of snow cover is considerably reduced in this higher elevation type (7000-8000 ft. [2120-2425 m]) by geothermal warming of the soil. Boundaries are relatively well defined as a consequence.

Component suffix - EH

Higher Elevation Mountainous Elk Winter Range

This winter range type is often contiguous, as a map unit, with the lower elevation (EL) type. Elk winter at these higher elevations primarily on windswept and exposed slopes or ridges where snowpack depth and duration are considerably reduced. Also included are winter ranges in valleys, such as the Duck/Cougar Creek area, which are characterized by deep winter snowpack. In general, heavier 
snowfall and deeper snowpack distinguish this type while elevation is considered to be a correlant with such conditions. Deeper snowpack in this winter range type serves to isolate wintering animals from and preclude their movement to ameliorated conditions of lower elevation winter range. Snow depth, aside from windswept ridges or other moderated microsites, generally exceeds $3 \mathrm{ft}$. ( $1 \mathrm{~m}$ ) during a significant portion of the winter. This winter range type should be mapped so as to encompass any sizeable group of elk (20+ animals) overwintering during an "average" winter.

Component suffix - EL

Lower Elevation Valley Elk Winter Range

This winter range type corresponds with lower elevations where winter weather conditions are significantly ameliorated. Temperatures are more-or-less moderated and snowfall significantly less than in adjoining and typically mountainous higher elevations.

Component suffix - CC

Carrion Concentrations

This type is most often associated with lower elevation winter range supporting ungulate populations at or near carrying capacity. It is characterized by a concentration of carrion and winter-weakened animals. Ideally, the "average" year should be used for delineating these areas.

Component suffix - UC

Treditional Ungulate Calving Grounds

This component type corresponds to areas where ungulates traditionally calve during late spring and early summer. Concentrations or groups of approximately 50 calving elk should be considered minimum for delineation of known calving grounds. In some cases traditional calving grounds may not exist for an ungulate subpopulation or population and so would not be delineated.

\section{Summer and Fall Range}

Component suffix - US

Summer-Fall High Use Ungulate Range

This tyoe is characterized by high density use, generally by bison or elk, during summer and fall. The presence of approximately 100 socially more-or-less cohesive animals is required for delineation of such a range type. A substantial portion of the greater Yellowstone area could conceivably be included in this type, however only prime habitat should be delineated. Characteristically, summer-fall high use range consists of productive mesic or subhydric nonforest areas interspersed with forest cover. As more data becomes available and as 
more information is synthesized, specific habitat criteria may be provided for delineation of this type.

\section{FISH DEFINED COMPONENTS}

Component suffix - FS

Fish Spawning Stream

This type consists of stream segments either used or potentially useable by grizzly bears, which support a sizeable fish spawning run. In many known cases, cutthroat trout comprise the run. Stream useability is either documented by observations or inferred from stream characteristics. Commonly the streams are (1) lower-gradient, (2) with a channel generally $<30 \mathrm{ft}$. $(10 \mathrm{~m})$ across and $<4 \mathrm{ft} .(1 \mathrm{~m})$ deep, and (3) with overhanging cutbanks associated with pools. Bears may fish upstream runs or the later downstream return of the fish. 


\section{LITERATURE CITED}

Christensen, A.G. 1982. Cumulative effects analysis process. U.S. Forest Service, Kootenai National Forest. $21 \mathrm{pp}$.

Gregory, S. 1983. Subalpine forb community types of the Bridger-Teton National Forest, Wyoming. M.S. Thesis, Montana State University.

Mattson, D. J. 1984. Classification and environmental relationships of wetland vegetation in central Yellowstone National Park. M.S. Thesis, Univ. of Idaho.

Mealey, S.P., G. Joslin, N. McKurray, S. Kiser, and C. Jonkel. 1976. Vegetation studies in disturbed grizzly habitat. pp 5-34 in C. Jonkel, ed., BGP Ann. Rept. No. 1. Univ. of MI, Missoula.

Mueggler, W.F and W.L. Stewart. 1980. Grassland and shrubland habitat types of Western Montana. USDA Forest Service Gen. Tech. Rpt. INT-66.

Pfister, R., B. Kovalchick, S. Arro, and R. Presby. 1977. Forest habitat types of Montana. USDA For. Serv. Gen. Tech. Rept. INT-34. 1974 pp.

Servheen, C.W. and L.C. Lee. 1979b. Mission Mountains grizzly studies an interim report. Border Grizzly Project. Montana Forest and Cons. Exp. Stn., School of Forestry, Univ. of MT, Missoula. 299 pp.

Steele, R., S. Cooper, D.M. Ondov, D.W. Roberts, and R.D. Pfister. 1983. Forest habitat types of eastern Idaho - western Wyoming. USDA For. Serv. Gen. Tech. Rept. INT-144. 122 pp.

Thomas, J.W., ed. 1979. Wildife habitats in managed forests, the Blue Mountains of Washington and Oregon. Agriculture Handbook No. 553. USDA For. Serv. 512 pp.

Tweit S.J. and K.E. Houston. 1980. Gressland and shrubland habitat types of the Shoshone Nat. For. Unpublished report.

Zager, P., R. Mace, and C. Jonkel. 1980. Grizzly bear habitat terminology. BGP Spec. Rept. No. 41. Univ. of MT, Missoula. $15 \mathrm{pp}$. 
Appendix A. Field form for component mapping.

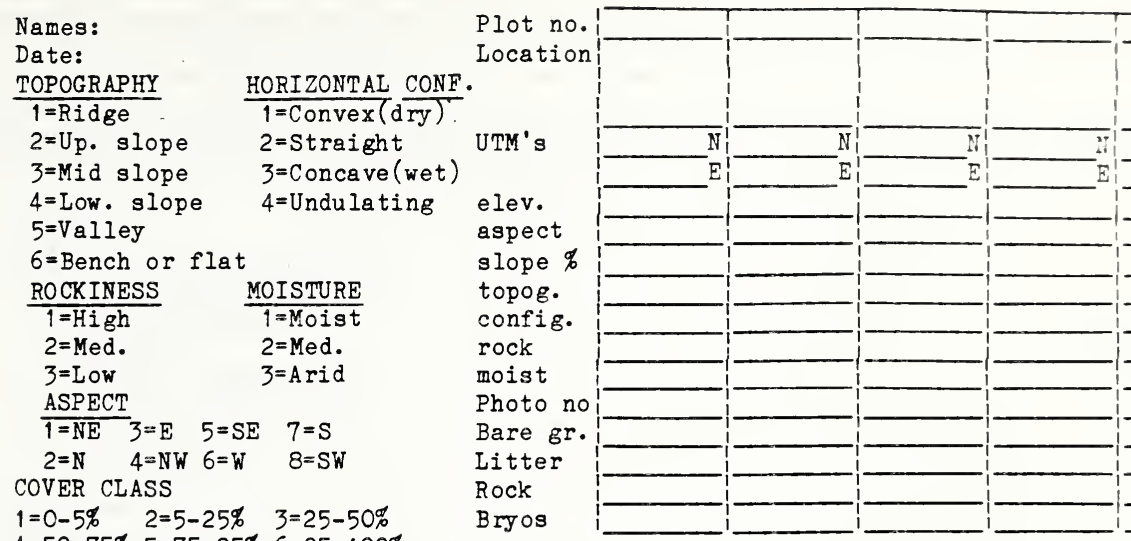

\section{$4=50-75 \% \quad 5=75-95 \% \quad 6=95-100 \%$} SHRUBS

TOTAL




\section{SHRUBS}

\section{GRAMINOIDS}

\section{FORBS}

\section{TREES}


APPENDIX B. PLANT SPECIES IMPORTANT TO GRIZZLY BEARS.

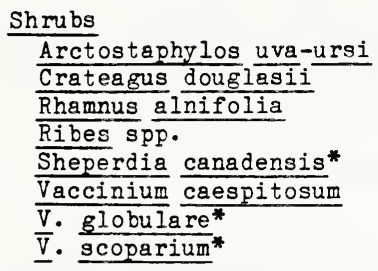

Forbs

Cirsium arvense

C. scariosum*

Claytonia lanceolata*

Epilobium angustifolium*

robust Epilobium spp. (e.g. E. glandulosum)

Equise tum arvense*

Equisetum spp.

Fragaria vesca

F. virginiana*

Heracleum lanatum

Lomatium cous*

L. dissectum

$\bar{L}$. triternatum

Perideridia gairdneri*

Polygonum bistortoides*

robust Polygonum spp. (e.g. P. amphibium)

Potamogeton spp. ( . natans, alpinus, etc.)

Streptopus amplexifolius

Taraxacum spp. (T. officinale, ceratophorum, etc.)*

Trifolium hybridum*

T. longipes*

T. repens $^{*}$

Graminoids

Agropyron spp.

Bromus spp.*

Calamagrostis spp.*

Carex spp.*

Deschampsia spp.*

Festuca spp.

Melica spp.*

Phleum spp*

Poa spp.*

Scirpus spp.

*Food items especially well-represented in the diet 
APPENDIX C. KEY TO NONFOREST HABITAT CONPONENTS.

1a. Open nonforest site $>2$ ha in size (2a).

2a. Shrubs dominant; combined shrub species cover, relative to total vegetation cover, $>50$ percent if low shrubs or $>33$ percent if tall shrubs (low shrubs average $\langle 1.5 \mathrm{~m}$ tall, tall shrubs $>1.5 \mathrm{~m}$ ).

SHRUB DOMINATED COMPONENTS (I), page 27

2b. Shrubs not dominant.

HERB DOMINATED CONPONENTS (II), page 28

1b. Nonforest site $<2$ ha in size; forest opening.

FOREST OPENING COMPONENTS (III), page 31

I. SHRUB DOMINATED COMPONENMS (00010)

1a. Tall shrubs (average $>1.5 \mathrm{~m}$, often exceeding $2 \mathrm{~m}$ in height) dominant; site of floodplain or streamide.

TALL SHRUB CONPONENT (00011) - tall shrub community

1b. Tall shrubs not dominant; low shrubs (average $<1.5 \mathrm{~m}$ tall) dominant (2a).

2a. Ceanothus velutinus dominant or codominant in dense mountain brush stand.

\section{MESIC-SUBXERIC FOREST OPENING CONEONENT}

(00042) - moist to dry forest opening.

2b. Ceanothus velutinus not dominart or codominant $\left(z_{a}\right)$.

3a. Sagebrush species (Artemisia spo.) or shrubby cinquefoil (Potentilla fruticosa) dominant; shrub foliage primarily silver-gray-green or dark green (4a).

4a. Potentilla gracilis, P. diversifolia, Agropyron caninum, Bromus carinatus, or Geranium viscossissimum akundant in some combination. Artemisia tridentata-vasevana, A. cana. or Potentilla fruticosa dominant ( $5 a$ ). 
5a. Mesic-hypermesic site of sidehill or floodplain with even or concave topography; soils predominately medium textured with little surface rock evident; herbaceous cover generally dense, moderate statured (ca. $6 \mathrm{dm}$ ), and dominated or codominated by graminoids; herbaceous vegetation usually remainir.g greer. through mid- to late July.

\section{MESIC-HYPERMESIC SAGEBRUSH/CINQUEFOIL COMPONENT (00012) - moist sagebrush/ cinquefoil shrub meadow}

5b. Mesic site of low ridge, upslope, or floodplain; soils predominantly rocky, not predominantly medium textured; surface rock very evident; herbaceous vegetation moderately open, not dense, and usually dominated by forbs; Artemisia tridentata-vaseyana dominant shrub.

MESIC/LITHIC SAGEBRUSH COMPONENT (00015) moist rocky sagebrush shrubland

4b. Mesic site species not abundant; Agropyron spicatum or, occasionally, Chrysothamnus spp. abundant. Artemisia tridentata, A. tripartita, or Purshia tridentata dominant or codominant.

SUBMESIC-SUBXERIC SAGEBRUSH COMPONENT (00013) - dry sagebrush shmubland

3b. Sagebrush species or shrubby cinquefoil not dominant; willow species (Salix spp.) dominant; shrub foliage green to grayish-green; site typically wet or of floodplain.

LOW WILLOW COMPONENT $(00014)$ - IOW WIIIOW shrub meadow

II. HERB DOMINATED COMPONENMS (00020 and 00030):

1a. Forbs prominent and typically dominant, comprising $>50$ percent of total vegetal cover; higher elevation sidehill, bench, or ridge site (ca).

2a. Senecio triangularis, Mimulus spp., or Heracleum lanatum dominant or abundant; subhydric site, soil persistently saturated by seepage; gentle to moderate slopes; vegetation succulent and green tinroughout the growing season; ccmponent boundary usually sharply delineated.

SUBHYDRIC FORB CORPONENT (00021) - fOrb dominated seep

2b. Mimulus spp. not abundant; drier site, not slibhydric; soil not persistantly saturated ( $3 a)$. 
3a. Caltha leptosepala, Ligusticum filicinum, Delphinium occidentale, Mertensia ciliata, Aconitum columbianum, Lupinus argenteus, or Rudbeckia occidentalis well represented to abundant alone or in some combination; vegetation generally dense, moderately tall (ca. $6 \mathrm{dm}$ ) and more-or-less diverse; mesic-hypermesic site of sidehill or bench.

4a. Caltha leptosepala, Aconitum columbianum, Senecio triangularis, Mertensia ciliata, or Rudbeckia occidentalis well represented or abundant alone or in some combination; hypermesic site, soil persistently wet to moist through the growing season; concave or sidehill site influenced by seepage; vegetation succulent and green late in the growing season (late August).

HYPERMESIC FORB COMPONENT (00022) - wet forb meadow

4b. Wet site forb species not present or not abundant; site drier, not hypermesic, soil drying by mid-July to early August; sidehill site or bench with even, convex, or concave topography; vegetation dried and brown by late July or early August.

\section{MESIC FORB COMPONEN' (00023) - moist forb meadow}

3b. Balsamorhiza sagittata, Helianthella uniflora, Artemisia ludoviciana, or Valeriana edulis well represented to abundant alone or in some combination; moister or wet site species not abundant; vegetation generally not dense, usually moderately open, moderate statured (ca. 4-6 dm); site submesic-subxeric, upslope sidehill or ridge; vegetation typically dried and brown by mid-July.

SUBMESIC-SUBXERIC FORB CCMPONEN" (00024) dry forb meadow

1b. Forbs not dominant although often prominent, total forb cover <50 percent of total vegetal cover ( $5 \mathrm{a})$.

5a. Carex aquatilis, C. rostrata, C. nebrascensis, C. vesicaria, or robust Scirpus spp. dominant alone or in combination. Subhydric site, sometimes inundated, soil persistently saturated; low slope seep or concave topography of floodplain or meadow; vegetation generally dense and moderately tall to tall (ca. 6-20 dm); foliage often dark green, remaining green throughout growing season. 
5b. Robust wet site Carex spp. and Scirpus spp. not dominant in species depauperate vegetation, although potentially present to well represented in combination with a greater number of drier site species; site drier, not subhydric, rarely inundated; vegetation low to moderate statured (ca. 3-6 dm), open to dense, and diverse $(6 \mathrm{a})$.

6a. Festuca idahoensis or Agropyron spicatum typically present and well represented; subxeric to submesic site; soil drying by mid-July to mid-August; flat, sidehill, or ridge site (7a).

7a. Agropyron caninum, Geranium viscossissimum, or Potentilla gracilis well represented to abundant, alone or in some combination; vegetation generally dense, moderate statured (ca. $6 \mathrm{dm}$ ) and more-or-less diverse; east to north or, less often, south exposures; vegetation dried and brown by late July to mid-August.

\section{MESIC GRAMINOID COMPONENT (00033) - moist grassland and meadow}

7b. Agropyron caninum, Geranium viscossissimum, and Potentilla gracilis not present or not well represented; vegetation moderately open, not dense, moderate to low statured (ca. 3-5 dm); bare ground or rock often evident; ridge or west to south facing sidehill except at lowest elevations ( $8 a$ ).

8a. Deschampsia elongata, Carex phaeocephala, and Lomatium cous present and well represented in some combination; rocky ridge and upslope at moderately high to high elevations (>8500 ft.).

MESIC-SUBMESIC/LITHIC GRAMINOID COMPONENT (00034) - high elevation rocky grassland

8b. High elevation dry site species not present; Agropyron spicatum, Stipa richardsonii, S. comata, or Poa sandbergii well represented; site not of high elevations; lower elevation or exposed south to west aspects.

\section{SUBXERIC GRAMINOID CONPONEN: (COO35) - dry grassland meadow}

6b. Festuca idahoensis and Agropyron spicatum not present except as sparsely represented occupants of microsites; wetter hypermesic site, soil wet to moist throughout growing season; vegetation generally dense, moderate statured (ca. $6 \mathrm{dm}$ ), and more-or-less diverse, ary by mid- to late August; Deschampsia cespitosa, Juncus balticus, Phleum alpinum, Carex microptera, Crepis muncinata, or Aster foliaceous well represented in some combination. 
HYPERMESIC GRAMINOID COMPONENT (00032) - wet meadow

III. FOREST OPENING COMPONENTS (00040):

1a. Calamagrostis canadensis, Glyceria spp., Senecic triagularis, or wet site Carex spp. well represented, of ten in some combination; hypermesic-subhydric site, soil persistently wet to moist; swale or streamside; graminoid or willow dominated vegetation, succulent throughout the growing season; vegetation dense and moderately tall (ca. 6-10 dm).

HYPERNESIC-SUBHYDRIC FOREST OPENING

COMPONENT (00041) - wet forest opening

1b. Wet site species not present; forest shrubs or herbaceous vegetation dominant; site drier, not hypermesic-subhydric; varied sidehill topography; vegetation variously drying or remaining green throughout the growing season.

MESIC-SUBXERIC FOREST OPENING COMPONENT

(00042) - moist to dry forest opening 
APPENDIX D. COVER TYPE CLASSES.

These cover types break the continuous process of succession into classes for the purpose of delineation on maps. It is recognized that stands in the latest stages of one class are more like the earliest stages of the next class than they are like the earliest stands of the same stage. Some difficulty will be encountered occasionally in the field in determining where to place a borderline type. However, just as many stands will be placed too high as are placed too low, canceling each other out in the evaluation process.

Ages given are only approximations and actual field measurements may vary considerably from that shown. The main criterion used to determine the cover type is the structure of the stand.

Cover type code numbers follow the ADP codes for Habitat Type Series in the Habitat Type manuals. 


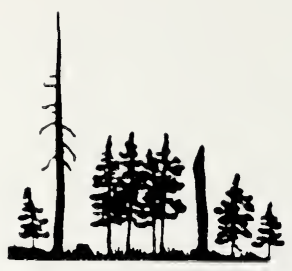

LODGEPOLE PINE MYPES

COVER TYPE - - 30 (LPO)

Recently burned or harvested lodgepole pine stands in the grass to seedling/sapling stage before canopy closure. Approximately $0-40$ years post fire.

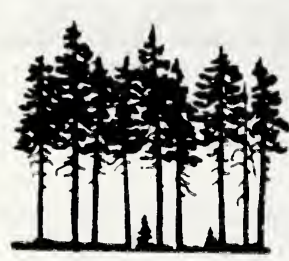

COVER TYPE ---31 (LP1)

Closed canopy of even-aged, usually dense, lodgepole pine where trees are younger and shorter than those of neighboring stands. Young pole successional stage. On outwash at West Yellowstone, it is represented by islands of scattered short trees next to islands of scattered larger trees. Approximately 40-100 years post fire.

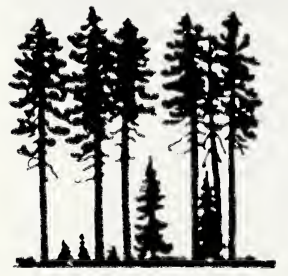

COVER TYPE ---32 (LP2)

Closed canopy dominated by lodgepole pine. Overstory still largely intact. Mature lodgepole pine successional stage. Uncerstory usually small to medium engelmann spruce and subalpine fir seedlings and saplings but also may be mostiy lodgepole pine. Approximately $100-300$ years post fire.

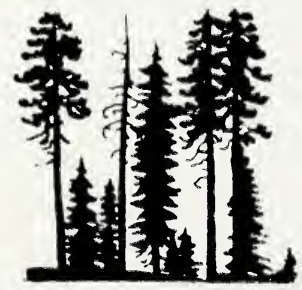

COVER TYPE --33 (LP3)

Canopy quite ragged, predominately of overmature lodgepole pine but containing some engelmann spruce, subalpine fir, and whitebark pine in the pole sized class. Old growth lodgepole pine successional stage. Understory of small to large spmce and fir seedlings and saplings. Three hundred plus yeers post fire.

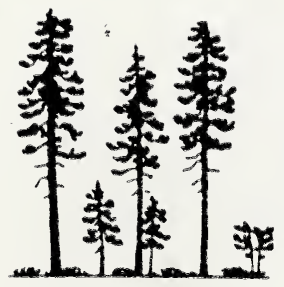

COVER TYPE ---34 (LP)

Canopy dominated by overmature lodgepole pine beginning to break up. Understory of Lodgepole pine and whitebark pine. Stands usualiy on rhyolite and multi-aged. Lodgepole is climax or persistent seral species. Three hundred plus years post fire. 

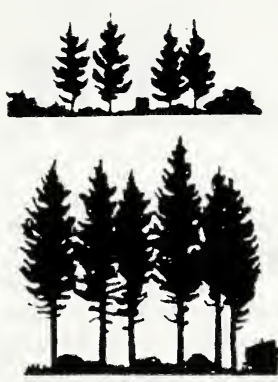

Closed canopy of usually dense, even-aged douglas-fir where trees are younger and shorter than those of neighboring stands. Young pole successional stage. Approximately 40 to 100 years post fire.

Burned or harvested, douglas-fir stands in the grass to seedling/sapling stage before canopy closure.

Reproduction mostly douglas-fir.

\section{COVER TYPE ---21 (DF1)}

Aproximately 40 to 100 jesrs post fire.

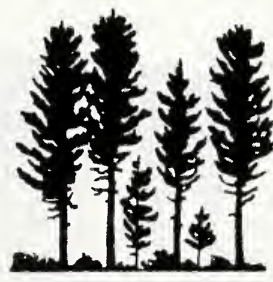

COVER TYPE --22 (DF2)

Closed canopy dominated by douglas-fir. Overstory still largely intact. Mature douglas-fir successional stage. Understory usually small to medium douglas-fir seedlings and saplings. Approximately 100-200 years post fire.

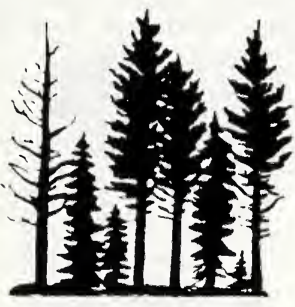

COVER TYPE $--23(D E 3)$

Canopy quite ragged, predominately of mature to overmature douglas-fir but containing some engelmann. sprice, subalpine fir, or whitebark pine in the pole sized class. Old growth douglas-fir successional stage. Understory of small to large spruce and fir seedlings and saplings. Three hundred plus years post fire.

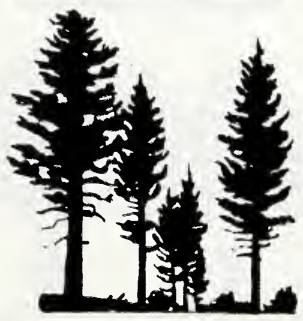

COVER TYPE $---24(D F)$

Climax to near climax stands dominated by mature to overmature douglas-fir, often in scattered islands in a nonforest matrix. 
Recently disturbed wet areas or high elevation cirques where reproduction is clearly dominated by engelmann spruce and subalpine fir. Canopy closure has not been achieved.

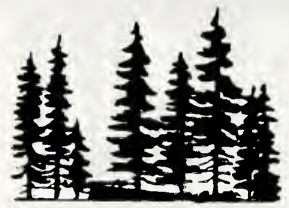

COVER TYPE ---41 (SFI)

Even-aged, closed stands dominated by sapling to pole sized englemann spruce and subalpine fir. Whitebark pine may also be a significant member. These stands commonly occur in high elevation cirques where shade and late melting snow make conditions unfavorable for lodgepole pine and whitebark pine. They may aiso be found in wet sites at lower elevations.

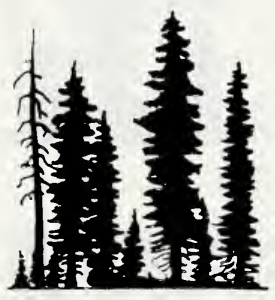

COVER TYPE ---44 (SF)

Stands dominated by engelmann spruce and subalpine fir in both overstory and understory. Lodgepole pine, douglas-fir or whitebark pine may be present, but are a minor stand component. 
WHITEBARK PINE TYPES

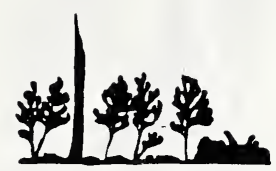

COVER TYPE ---50 (WBO)

Recently burned whitebark pine stands usually near upper timberline where whitebark pine cleariy dominates reproduction.

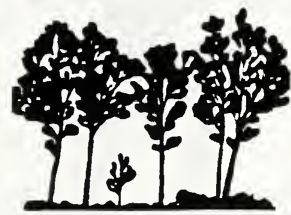

COVER TYPE ---51 (WB1)

Even-aged, closed whitebark pine stands where trees are younger and shorter than those of neighboring stands. Trees are small pole sized.

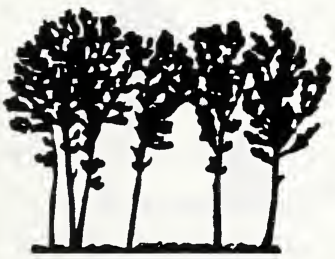

COVER TYPE ---52 (WB2)

Closed canopy dominated by whitebark pine. Overstory still largely intact. Trees pole to mature sized. Understory usually small to medium engelmann spruce and subalpine fir seedlings and saplings but may be mostly whitebark pine. Approximately $100-300$ years post fire.

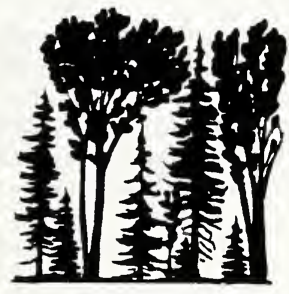

COVER TYPE ---53 (WB3)

Stands dominated by mature whitebark pine and may also contain considerable engelmann sprice, subalpine fir, or lodgepole pine. Understory is a combination of engelmann spruce, subalpine fir and witebark pine.

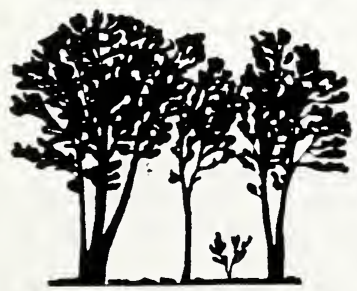

COVER TYPE ---54 (WB)

Stands of mature to overmature whitebark pine where the reproduction is nearly all whitebark pine. 
COVER TYPE $-\cdots 70$ (ASPO)
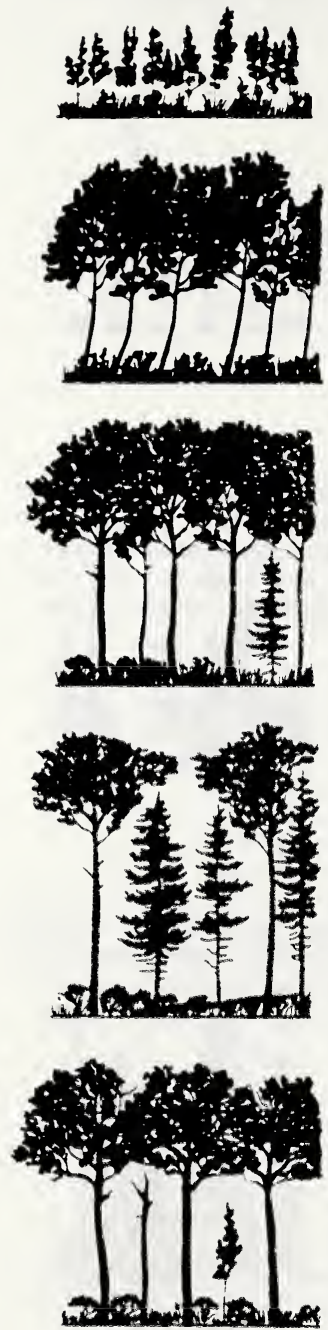

Early post-disturbance stands with predominantly sapling sized aspen. Trees are usually less than 10 ft. tall. Some stands may be maintained in this type by harsh environmental conditions, heavy browsing or both.

COVER TYPE ---71 (ASP1)

Stands of predominantly small, pole sized, usually vigorous trees. Some stands may be relatively old, but stunted by environmental conditions.

\section{COVER TYPE -.72 (ASP2)}

Stands of pole sized to mature trees with more-or-less even canopy and little mortality.

\section{COVER TYPE $\ldots-73$ (ASP3)}

Mature to overmature stand with well represented to abundant presence of conifer species in sapling to pole or occasionally mature size and age classes. The overstory is at or near the point of breaking up and being replaced by the energing coniter understory.

COVER TYPE -.74 (ASP)

Mature to overmature gtand where aspen is climax or a long persistent seral species; sapling or pole sized aspen are usually weIl represented and indicates the persistence of aspen dominance through at least another stand cycle. Conifer species representarion is linited to a few individuals, typically of saplire to mature classes. 


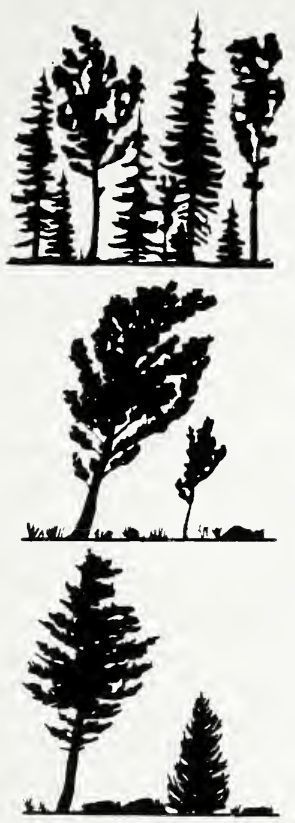

LIMBER PINE TYPES

COVER TYPE - - 13 (LI3)

Stands are dominated by mature limber pine and may also contain considerable douglas-fir, engelmann spruce, subalpine fir or lodgepole pire. Understory is a combination of douglas-fir or ergelmann spruce and subalpine fir.

COVER TYPE ---14 (LI)

Stands of mature to overmature limber pine where the reproduction is nearly all limber pine. This and the preceeding type are almost exclusively found on the east slopes of the Absaroka Rarge.

COVER TYPE ---64 (OW)

Open woodland with Juniperus scopulorum dominant. Douglas-fir and limber pine are present and sometimes dwarfed in appearance due to extremely harsh site conditions. Understory species dominated by bluebunch wheatgrass, Idaho fescue and Artemisia spp. Density of ten capable of providing cover.

MIXED FOREST TYPES

MF1 - Mixed forest stand in early successional stage. Canopy typicaliy

81 closed and comprised of sapling to pole sized trees.

MF2 - Stand of large pole to mature sized trees in mid-successional stage, 82 still a more or less even stand structure.

MF - Late successional to climax stage, varied stmcture and age class

84 representation, with mature to overmature individuals of "early" and "late" successional species in the overstory.

MISCELLANEOUS TYPES

LPP - Lodgepole pine pigmy forests found mostly on Hadison Plateau.

62 Multi-aged dwarfed lodgepole pine with a grass understory (height up to ten feet).

KH - Krumholtz stands consisting of dwarfed, wind-shaped engelmann spruce,

63 subalpine fir, and whitebark pine stands. Usually islands interspersed in nonforest at upper tree line. 


